R H M and M R were funded by the E P Abrahams Research Fund. K G is funded by the Medical Research Council. We are grateful to Dr P Griffiths for statistical advice. We also thank our referees and Dr R Jacoby for their comments on thank our refer
earlier drafts.

1 McKeith IG, Fairbairn AF, Perry RH, Thompson P. The clinical diagnosis and misdiagnosis of senile dementia of Lewy body type (SDLT). Br F Psychiatry 1994;165: 324-32.

2 Crystal HA, Dickson DW, Lizardi JE, Davies P, Wolfson LI. Antemortem diagnosis of diffuse Lewy body disease. Neurology 1990;40:1523-8.

3 Byrne EJ, Lennox GG, Godwin-Austen RB, et al. Dementia associated with cortical Lewy bodies: proposed clinical diagnostic criteria. Dementia 1991;2. 283-4.

4 Hansen L, Salmon D, Galasko D, et al. The Lewy body variant of Alzheimer's disease. Neurology 1990;40:1-8.

5 Wragg RE, Jeste DV. Overview of depression and psychosis in Alzheimer's disease. Am $\mathcal{J}$ Psychiatry 1989;146:577-87.

6 Perry RH, Irving D, Blessed G, Fairbairn A, Perry EK. Senile dementia of Lewy body type. A clinically and neuropathologically distinct form of Lewy body dementia in the elderly. F Neurol Sci 1990;95:119-39.

7 Ince P, Irving D, MacArthur F, Perry RH. Quantitative neuropathological study of Alzheimer-type pathology in the hippocampus: comparison of senile dementia of Alzheimer type, senile dementia of Lewy body type, Parkinson's disease and non-demented elderly control patients. F Neurol Sci 1991;106:142-52.

8 Dickson DW, Schmidt ML, Lee VM, Zhao ML, Yen SH,
Trojanowski JQ. Immunoreactivity profile of hippocampal CA2/3 neurites in diffuse Lewy body disease. Acta Neuropathol (Berl) 1994;87:269-76.

9 Lippa CF, Smith TW, Swearer JM. Alzheimer's disease and Lewy body disease: a comparative clinicopathologiand Lewy body disease: a comparative

10 Teunisse JR, Cruysberg JRM, Verbeek A, Zitman G. The Charles Bonnet syndrome: a large prospective study in The Netherlands. Br $\mathcal{F}$ Psychiatry 1995;166:254-7.

11 Merriam AE, Aronson MK, Gaston P, et al. The psychiatric symptoms of Alzheimer's disease. $¥ \mathrm{Am}$ Geriatr Soc 1988;36:7-12.

12 Hope T, Fairburn CG. The Present Behavioural Examination (PBE): the development of an interview to measure current behavioural abnormalities. Psychol Med 1992;22:223-30.

13 Folstein MF, Folstein SE, McHugh PR. "Mini-mental state": a practical method for grading the cognitive state of patients for the clinician. $\mathcal{F}$ Psychiatr Res 1975;12: of patients

14 Kosaka K. Diffuse Lewy body disease in Japan. $f$ Neurol 1990;237:197-204.

15 Lennox G, Lowe J, Landon M, Byrne EJ, Mayer RJ, Godwin-Austen RB. Diffuse Lewy body disease: correlative neuropathology using anti-ubiquitin immunocytochemistry. $f$ Neurol Neurosurg Psychiatry 1989;52: 1236-47.

16 Mirra SS, Hart MN, Terry RD. Making the diagnosis of Alzheimer's disease. A primer for practicing pathologists. Arch Pathol Lab Med 1993;117:132-44.

17 Forstl H, Burns A, Luthert P, Cairns N, Levy R. The Lewy-body variant of Alzheimer's disease. Clinical and pathological findings. Brf Psychiatry 1993;162:385-92.

\section{A note on Claude Bernard-Horner's syndrome}

Claude Bernard (1813-78), born in St Julien in Rhone, reported in 1852 his experiments on cutting the rabbit's cervical sympathetic nerve. He observed that this caused constriction of the ipsilateral pupil, but also flushing and a rise in temperature of the ear. From this he deduced for the first time that sympathetic nerves (vasomotor) controlled flow in blood vessels. ${ }^{1}$

Horner described the triad of ptosis, miosis, and enophthalmos in 1869 . Though known by his name, earlier, but sometimes incomplete, accounts exist in the writings of Pourfour du Petit. ${ }^{2}$ Weir Mitchell ${ }^{3}$ however, gave the first full account five years before Horner, describing a 24 year old soldier with a gunshot wound of the right side of his neck:

"The pupil of the right eye is very small ... slight but very distinct ptosis . . . The ball of the right eye looks smaller than that on the left ... The conjunctiva is somewhat redder... and the pupil somewhat deformed, oval rather than round ... his face became distinctly flushed on the right side only when walking in warm weather ... a case of injury of the sympathetic nerve, probably the only one recorded."

The soldier's signs recovered in five months and he returned to military duties.

Thirty years earlier Edward Selleck Hare, House Surgeon to Stafford County General Infirmary, had described the physical signs in a letter ${ }^{4}$ to the Medical Gazette on 11 September 1838. His patient was a Thomas Willetts aged 40 with:

"pain, tingling and numbness along the course of the ulnar nerve of the left arm, ... and a small tumour in the inferior triangular space on the left side of the neck ... the pupil of the left eye became contracted; and the levator palpebrae ceased to perform its office."... He died within 10 weeks. Postmortem showed extensive infiltration of the brachial plexus, jugular and carotid vessels, anterior mediastinum, vagus and "the sympathetic, with its lower cervical ganglion." Hare could not relate the ocular signs to the structural disease, "they must be regarded as an instance of that remote sympathy which is found to exist between distant parts of the same individual ...."

Sadly, Hare died on 28 September 1838 aged 26 of typhoid fever.

Horner's paper ${ }^{5}$ was translated by Fulton ${ }^{6}$ :

"Anna Brändli, aged 40, a healthy looking peasant

woman... six weeks after her last confinement noticed a slight drooping of her right upper eyelid, which increased very gradually... The upper lid covers the right cornea to the upper edge of the pupil; the lid is not loose or wrinkled but somewhat sunken into the orbit and is still capable of movement; it is neither injected nor swollen. The upper convex furrows of the forehead indicate that the frontalis muscle is working as a substitute [for the levator palpebrae superioris]

The pupil of the right eye is considerably more constricted than that of the left, but reacts to light; the globe has sunk inward very slightly ... During the clinical discussion... the right side of her face became red and warm; while the left side remained pale and cool. The right side seemed turgid and rounded, the left more sunken and angular; the one perfectly dry, the other moist. The boundary of the redness and warmth was exactly in the midline. The patient thereupon told us that the right side had never perspired . . I Immediately after application, the thermometer on the right recorded $35 \mathrm{C}$, that on the left, 30C, ..."

Horner measured temperature behind the ear and in the axilla and groin.

"After application of atropine into each conjunctival sac the right pupil enlarged slowly and irregularly; after twenty minutes it had not reached the size of the left... When 24 hours after atropine, equal quantities of calabar ${ }^{\star}$ were put into the conjunctival sac of each eye, one noticed after ten minutes a marked constriction on the right; while on the left the action of atropine still continued ..."

Considering the cause of each sign in turn, Horner concluded:

"the vasomotor disturbance involves not only the trigeminal area, but also the fibres of the cervical sympathetic; this experiment with belladonna and calabar speaks for the dual control of the movements of the iris in man ... we are dealing with right dilator paralysis ... Ptosis ... a paralysis of the musculus palpebrae superioris supplied by the sympathetic nerve ( $H$. Müller, Harling), and the appearance of the upper lid as part and parcel of the whole symptom-complex."

Johann Friedrich Horner (1831-86) was born in Zurich. His medical studies were profoundly influenced by the physiologist Karl Ludwig. After graduating in 1854 he visited Munich and Vienna and continued on page 191

* Calabar is the extract from the seed of a woody vine Physostigma venenosum containing physostigmine, which was used by Argyll Robertson in 1863 for examining the pupils. 
subsequently, may have been examples of CIDP, as nerve biopsy abnormalities were non-specific, and a family history of neurological disease was often absent ${ }^{2-47101213}$ or at best questionable. ${ }^{51114}$ Our patient shows definitively that spinal compression syndromes may occur in acquired hypertrophic neuropathies as well as in HMSN and expands the spectrum of the clinical presentation of CIDP.

We thank Dr R H M King and Miss J Workman for assistance with the histopathological studies. 1 Thomas PK, Lascelles RG, Stewart G. Hypertrophic neuropathy. In: Vinken PJ, Bruyn GW, eds. Handbook of clinical neurology, Vol 21, system disorders and atroph

2 Bruns G. Zur Kenntnis der hypertrophischen Neuritis (Roussy-Cornil). Beitr Path Anat 1951;111:407-18.

3 Roger H, Poursines Y, Gallais P, Roger J. Polynévrite hypertrophique de l'adulte (nonfamiliale) avec paraparésie spasmodique. Rev Neurol 1952;86:695-8.

4 Lewtas NA, Dimant $S$. The diagnosis of hypertrophic interstitial polyneuritis by myelography. $f$ Fac Radiol 1957;8:276-9.

5 Symonds CP, Blackwood W. Spinal cord compression in hypertrophic neuritis. Brain 1962;85:251-60.

6 Andermann F, Lloyd-Smith DL, Mavor H, Mathieson G. Observations on hypertrophic neuropathy of Dejerine and Sottas. Neurology 1962;12:712-24.
7 Hinck VC, Sachdev NS. Myelographic findings in hypertrophic interstitial neuritis. AfR Am F Roentgenol 1965; 95:947-8.

8 Bellon EM, Kaufman B, Tucker ME. Hypertrophic neuropathy: plain film and myelographic changes. Radiology 1972;103:319-22.

9 Kremenitzer M, Ager PJ, Zingesser LH. Myelographic evidence for nerve root enlargement in a case of Charcot-Marie-Tooth disease. Neuroradiology 1976;11: 165-7.

10 Hammerschlag SB, Adelman LS, Marcus EM, Wolpert SM. Cervical myelographic changes in hypertrophic interstitial polyneuropathy. Ann Neurol 1977;2:83-4

11 Carlin L, Biller J, Challa V, Riela A. Hypertrophic neuropathy with spinal cord compression. Surg Neurol 1982;18:237-40.

12 Miura T, Hirabuki N, Imakita S, Harada $K$, Kawai R, Mitomo M, Takahashi M. Radiological findings in a case of Charcot-Marie-Tooth disease $\mathrm{Br} f \mathrm{f}$ Radiol 1985;58:1017-20.

13 Morano JU, Russell WF. Nerve root enlargement in Charcot-Marie-Tooth disease: CT appearance. Radiology 1986;161:784

14 Rosen SA, Wang H, Cornblath DR, Uematsu S, Hurko O. Compression syndromes due to hypertrophic nerve roots in hereditary motor sensory neuropathy type 1 . Neurology 1989;39:1173-7.

15 Crino PB, Grossman RI, Rostami A. Magnetic resonance imaging of the cauda equina in chronic inflammatory demyelinating polyneuropathy. Ann Neurol 1993;33: 311-3.

16 Pollard JD. Chronic inflammatory demyelinating polyneuropathy. In: McLeod JG, ed. Baillière's clinical neurology: inflammatory neuropathies. London: Baillière Tindall, 1994:107-27

17 Prineas JW. Pathology of inflammatory demyelinating neuropathies. In: McLeod JG, ed. Baillière's clinical neurology: inflammatory neuropathies. London: Baillière Tindall, 1994:1-24.

\section{A note on Claude Bernard-Horner's syndrome continued from page 188}

acquired a lifelong interest in eye diseases. He worked with von Graefe who became his close friend. In 1862 he was appointed Professor of ophthalmology in his home town. Apart from his studies of cervical sympathetic paralysis, he described a man with red-green colour blindness who had transmitted the disorder to his male grandchildren through an unaffected daughter: establishing sex linked transmission. Analby, Hull HU10 7BG, UK
1 Bernard C. Sur les effets de la section de la portion céphalique du grand sympathique. Comptes Rendus. Société de Biologie, Paris 1852;4:168-9.

2 Pourfour du Petit F. Mémoire dans lequel il est démonstré que les nerfs intercosteaux fournissent des rameaux qui portent des esprits dans les yeux. Histoire de l'Académie Royal des Sciences, Paris, Mémoires 1727;1-19.

3 Mitchell SW, Morehouse GR, Keen WW. Gunshot wounds and other injuries to nerves. Philadelphia: Lippincott, 1864.

4 Hare ES. Tumour involving certain nerves. London Medical Gazette 1838;23:16-8.

5 Horner F. Ueber eine Form von Ptosis. Klinische Monatsblätter für Augenheilkunde 1869;7:193-8, translated by JF Fulton. ${ }^{\circ}$

6 Fulton JF. Horner and the syndrome of paralysis of the cervical sympathetic. Arch Surg 1929;18:2025-39. 